\title{
Bear Creek Watershed Investigation
}

\author{
by Graham Hillman ${ }^{1}$ and Richard Rothwell²
}

\section{ABSTRACT}

The Bear Creek Watershed Investigation was initiated to obtain hydrological data from the northern part of Alberta because there were no data existing on this unique region in the province. Investigators were interested in developing a basic understanding of flood discharges, runoff, and retention capacity with the idea of potential future harvesting of northern Alberta forests or introducing agriculture in the future. Unfortunately, problems with accessibility and cost of maintenance resulted in the project being abandoned. This summary outlines the basic data that were collected during this project.

\section{RÉSUMÉ}

Létude du bassin versant de Bear Creek a été amorcée afin d’obtenir des données hydrologiques pour le nord de l’Alberta, car il nexistait aucune information en la matière pour cette région particulière de la province. Les chercheurs visaient à acquérir des notions de base sur les débits de crue, le ruissellement et la capacité de rétention pour le cas où l'on envisagerait un jour de récolter les forêts ou de faire de l'agriculture dans le nord de l'Alberta. Malheureusement, les problèmes d’accessibilité et les coûts d'entretien ont provoqué labandon du projet. Cette synthèse fait ressortir les informations de base qui ont pu être recueillies en marge de ce projet.

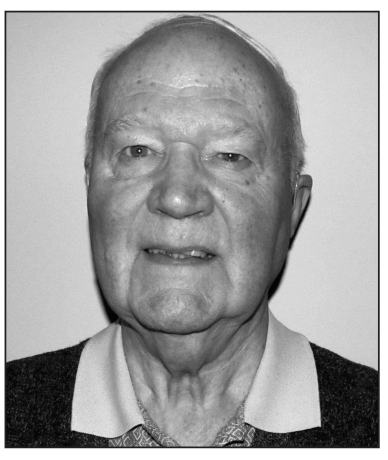

Graham Hillman

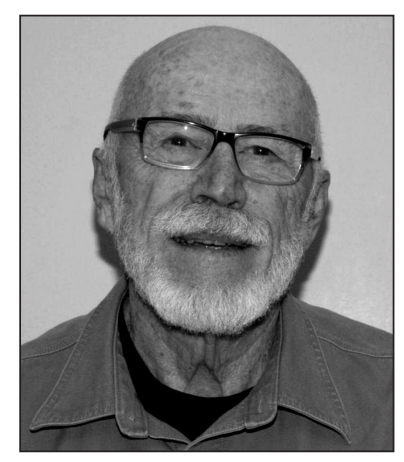

Richard Rothwell

\section{Introduction}

The Bear Creek Watershed Investigation was initiated in 1967 because there was a need to obtain hydrological data from the northern part of Alberta (Table 1) - an area hydrologically distinct from the rest of the province with low precipitation and runoff rates. The landscape in and around the Bear Creek watershed is characterized as "mountain" plateau, foothills, and lowland flats. The study was designed to answer basic questions pertaining to specific flood discharges, runoff volumes per unit area, and retention capacity of swampy flats with no clearly defined drainage network. The long-term objective was to collect and compile hydrological data on rainfall-runoff conditions in the northern part of Alberta for future development (e.g., forestry, agriculture) of northern forest regions (Holocek 1971).

Data collection started near the end of 1968 but the watershed project was terminated during the beginning of 1973 with four years of incomplete record (Table 1). The virtual

impossibility of reaching the site and the high costs of maintenance were given as reasons for the abandonment (Card and Abraham 1981).

\section{Instrumentation}

Instrumentation (Fig. 1) consists of:

a) a recording stream gauge at the outlet of Bear Creek (\#1)

b) a recording stream gauge at the foot of Buffalo Head Hills $(\# 2)$

c) a non-recording stream gauge on the other major stream (\#3).

d) recording precipitation gauges at sites \#2 and \#4.

\section{Results and Discussion \\ Precipitation}

Precipitation data collected from the Bear Creek watershed (summer 1970) suggest that the Buffalo Head Hills area is a prime recharge area, contributing considerably more water to the Bear Creek watershed than the flat lowland further downstream. At Fort Vermilion, $46 \mathrm{~km}$ north of station \#2, $195 \mathrm{~mm}$ of precipitation was recorded in summer. Meteorological stations at the top (\#4) and the base (\#2) of the Buffalo Head Hills recorded $335 \mathrm{~mm}$ and $275 \mathrm{~mm}$, respectively, for the same period. The corresponding total precipitation for 1970 was: $310 \mathrm{~mm}$ (Fort Vermilion), $432 \mathrm{~mm}$ (\#4) and $416 \mathrm{~mm}$ (\#2; Holocek 1971).

\section{Runoff}

Integral curves (cumulative runoff for the year April 1 to March 31 expressed in percentage of total annual runoff) developed for Bear Creek hydrometric stations \#1 and \#2 (1969-1970 data) were compared with those for the North Saskatchewan River at Saskatchewan Crossing, Sturgeon

\footnotetext{
${ }^{1}$ Natural Resources Canada, Canadian Forest Service, Northern Forestry Centre, Edmonton, Alberta

${ }^{2}$ Department of Renewable Resources, University of Alberta, Edmonton, Alberta
} 
Table 1. Summary of Bear Creek watershed and climatic characteristics.

\begin{tabular}{|c|c|}
\hline & Watershed Location and Data \\
\hline $\begin{array}{l}\text { Location } \\
\text { (descriptive) }\end{array}$ & $\begin{array}{l}555 \mathrm{~km} \text { NW of Edmonton } \\
\text { Stream gauge \#1: } 17 \mathrm{~km} \text { SE of Fort Vermilion } \\
\text { Stream gauge \#2: } 46 \mathrm{~km} \mathrm{~S} \text { of Fort Vermilion, } \\
\text { at the foot of Buffalo Head Hills. Aspect is NE }\end{array}$ \\
\hline $\begin{array}{l}\text { Location } \\
\text { (geographic) }\end{array}$ & N 57 $56^{\prime} 13^{\prime \prime}, \mathrm{W} 115^{\circ} 58^{\prime} 58^{\prime \prime}$ \\
\hline $\begin{array}{l}\text { Watershed } \\
\text { area }\end{array}$ & $\begin{array}{l}\text { (Stream gauge \#1) } 508 \mathrm{~km}^{2} \text {; (Stream gauge \#2 } \\
\quad 77 \mathrm{~km}^{2}\end{array}$ \\
\hline Elevation & $825 \mathrm{~m}$ to $275 \mathrm{~m}$ \\
\hline Vegetation & $\begin{array}{l}\text { Black spruce (Picea mariana (Mill) BSP, } \\
\text { sedge (Carex sp.), phreatophitic grasses } \\
\text { (calamagrostis sp.) and willows (Salix sp.) }\end{array}$ \\
\hline $\begin{array}{l}\text { Precipitation } \\
\text { (mean annual) }\end{array}$ & $356 \mathrm{~mm}(59 \%$ as rainfall $)$ \\
\hline Runoff & $\begin{array}{l}\text { Flow Records: } \\
\text { Stream gauge \#1 (outlet): } \\
\text { Average annual runoff (1968-1970): } 30 \mathrm{~mm} \\
\text { Excluding spring flood wave: } 18 \mathrm{~mm} \\
\text { Highland plateau spring runoff: } 7.5 \mathrm{~mm} \\
\text { Lowland spring runoff: } 4.5 \mathrm{~mm} \\
\text { Annual runoff (1968-1969): } 47 \mathrm{~mm} \\
\text { Excluding spring flood wave: } 17.4 \mathrm{~mm} \\
\text { Highland plateau spring runoff: } 8.5 \mathrm{~mm} \\
\text { Lowland spring runoff: } 21.6 \mathrm{~mm} \\
\text { Annual runoff (1969-1970): } 18 \mathrm{~mm} \\
\text { Excluding spring flood wave: } 14.4 \mathrm{~mm} \\
\text { Highland plateau spring runoff: } 1 \mathrm{~mm} \\
\text { Lowland spring runoff: } 2.5 \mathrm{~mm}\end{array}$ \\
\hline
\end{tabular}

Stream gauge \#2 (at foot of Buffalo Head Hills): Average annual runoff (1968-1970) from highland plateau: $322 \mathrm{~mm}$

Average spring runoff from highland plateau: $42 \mathrm{~mm}$

Annual runoff (1968-1969): 333 mm

Spring runoff (1968-1969): $56.6 \mathrm{~mm}$

Annual runoff (1969-1970): 262mm

Spring runoff (1969-1970): $8 \mathrm{~mm}$

Temperature Mean monthly air temperatures range from a low of $-22.7^{\circ} \mathrm{C}$ in January to a high of $16.9^{\circ} \mathrm{C}$ in July. Mean annual temperature is $-0.9^{\circ} \mathrm{C}$.

Study duration 1968-1973

River at Fort Saskatchewan, and Spring Creek near Valleyview. The Bear Creek \#1 integral curve closely followed the integral curve for Sturgeon River; however, the Bear Creek \#2 integral curve more closely followed that of the North Saskatchewan River. The Bear Creek \#2 curve likely reflects the high-mountain character of the North Saskatchewan. Conversely, runoff at Bear Creek \#1 (outlet) has the characteristics of a lowland stream. The amount of runoff retained by the wetland annually was estimated to be $161 \mathrm{~mm}$ (Holocek 1971).

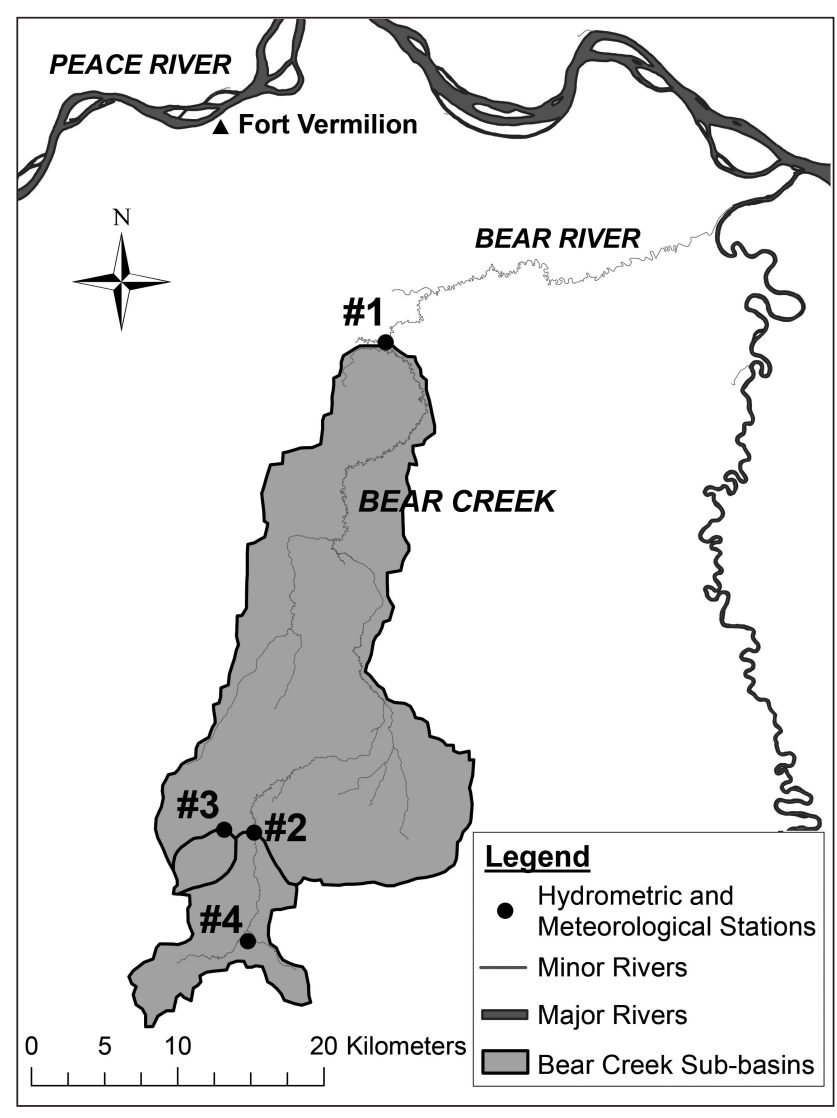

Fig. 1. Bear Creek Watershed with hydrometric and meteorological stations indicated for sub-basins.

\section{Summary}

Summer precipitation and total precipitation were greatest on the highland and foothills of Buffalo Hills.

Runoff from the highland plateau and foothills:

- has the characteristics of a modified mountain stream

- is characterized by high base flow and unit discharge values

- is controlled by the low wetland which modifies extremes of flow

Runoff at the outlet:

- has the characteristics of a lowland stream

- is characterized by low base flow and unit discharge values

- is completely controlled by the wetland

- has negligible local inflow, except for during the snowmelt period, as more than $50 \%$ of the input from the highland headwater area is generally trapped in the wetland (Holocek 1971).

\section{References}

Card, J.P. and C. Abraham. 1981. Bear Creek Watershed Report No. 2. Alberta Environment, Technical Services Division, Environmental Engineering Support Services, Hydrology Branch, Edmonton, Alberta. $56 \mathrm{p}$.

Holocek, G. 1971. Bear Creek Watershed Investigation. Report No. 1 Calendar Year 1969-1970. Alberta Department of Agriculture, Water Resources Division, Hydrology Branch, Edmonton, Alberta. $107 \mathrm{pp}$. 